\title{
SIGNIFICANCE OF CLAY MINERALS IN PETROPHYSICAL PROPERTIES FROM CARBONATES OF THE COTINGUIBA FORMATION
}

Clarissa O. da Luz, Mariléa G. Santos, Gerson Cardoso da Silva Jr.

Copyright 2019, SBGf - Sociedade Brasileira de Geofísica

This paper was prepared for presentation during the $16^{\text {th }}$ International Congress of the Brazilian Geophysical Society held in Rio de Janeiro, Brazil, 19-22 August 2019.

Contents of this paper were reviewed by the Technical Committee of the $16^{\text {th }}$ International Congress of the Brazilian Geophysical Society and do not necessarily represent any position of the SBGf, its officers or members. Electronic reproduction or storage of any part of this paper for commercial purposes without the written consent of the Brazilian Geophysical Society is prohibited.

\begin{abstract}
Cotinguiba Formation (Sergipe-Alagoas Basin) consists of carbonates interlayered with fine to coarse clastic sediments, deposited in a maximum inundation during the Cenomanian-Coniacian transgressive event. Nineteen core sections were selected representing the main carbonates in the formation, from those 20 plugs were obtained representing the main carbonates presents in Cotinguiba Formation. The selected samples were analyzed petrophysical and physically through air porosimetry, mercury injection and acoustic wave velocity; and mineralogically through optical microscopic analysis, x-ray diffraction (XRD) and scanning electron microscopy (SEM).
\end{abstract}

The results obtained showed that the content of clay minerals in the carbonates varies from $2 \%$ to $20 \%$, with the most abundant clay minerals being illites/micas and interstratified illite/smectite, with traces of chlorite and kaolinite, and presence of palygorskite varying trace to $8 \%$. According with the percentages of calcite, dolomite and siliciclastic+clay obtained in the XRD analysis, the carbonates were lithologic identified as limestone, impure limestone, dolomitic limestone, impure dolomitic limestone, impure calcitic dolostone and impure dolostone. It was evidenced a good porosity in the rocks with percentages of $6 \%$ to $20 \%$ in the carbonates, predominantly related to microporosity.

Clay minerals content influenced in values of grain density and acoustic properties, not having the same role with porosity and permeability, but SEM images shows that they have an important role in the microporosity. Grain density variation in relation to the phyllosilicate content was observed more significantly in impure limestones with a clay content higher than $8 \%$, with a higher decrease observed in samples with palygorskite. Microporosity is the main factor for reduce $\mathrm{Vp}$ and $\mathrm{Vs}$ velocities in those carbonates, with values not exceeding $5341 \mathrm{~m} / \mathrm{s}$ for $\mathrm{Vp}$ and $3026 \mathrm{~m} / \mathrm{s}$ for $\mathrm{Vs}$, but when clay content is higher than $4 \%$ it is observed that the $\mathrm{Vp}$ and Vs wave velocities do not exceed $4100 \mathrm{~m} / \mathrm{s}$ and 2480 $\mathrm{m} / \mathrm{s}$, respectively.

\section{Introduction}

Carbonate rocks have a large diversity of depositional facies and a very complex porosity system. Knowing the properties of these rocks is a continuous process of analysis and research in development, since the complexity of these rocks makes their study extremely challenging (Spadini \& Marçal, 2005).

The Sergipe-Alagoas Basin is located in the Northeastern region of Brazil and presents the most complete sedimentary succession along the basins of the Brazilian east margin with twenty-three depositional sequences. Initially the basin lithostratigraphy was characterized by Feijó (1994) and revised by Campos Neto et al. (2007). During the Neocenomanian a transgressive event, that extended until Coniacian, resulted in the deposition of sediments of the carbonatic ramp of the Cotinguiba Formation (Koutsoukos, 1989).

Bandeira Jr. (1977) has identified that the Cotinguiba Formation consists of layers of carbonates locally interspersed with fine to coarse clastic sediments and is divided into two members: Aracaju and Sapucari. The Aracaju member is composed of fossiliferous micrites and biomicrites, with calcispheres, planktonic foraminifera, fragments of pelecypods, equinoids and ostracod shells. The carbonates from this member are interlayered with unconsolidated gray to dark brown calciferous shales and moderately friable gray to green shales. The Sapucari member is formed by clayey cryptocrystalline limestones grading to marl, dolomitic limestones and dolomites (Bandeira Jr., 1977).

Cotinguiba Formation's rocks are generator at the Cotinguiba-Calumbi oil system, and can also behave as a reservoir when naturally fractured, which can be observed in the field of Angelim. Considering the importance of these rocks as reservoirs bearing hydrocarbons, the petrophysical characterization of this formation becomes essential for better information to be used to better evaluate the productive potential of the reservoir.

With the aim of better understand how petrophysical parameters are influenced by clay minerals from the carbonates of Cotinguiba Formation, the main carbonate types identified were analyzed through air porosimetry, mercury injection and acoustic wave velocity to identify petrophysical and physical properties; and with optical microscopic analysis, x-ray diffraction and scanning electron microscopy, for mineralogical characterization.

\section{Method}

Seventeen core sections that represented the main carbonates from Cotinguiba Formation were selected 
from the core 2-LRJ-01-SE. The well 2-LRJ-01-SE was drilled in a Votorantim Cimentos' limestone mine at Nossa Senhora do Socorro in Sergipe, Brazil. From the selected core section 20 plugs with 1.5 -inch diameter were obtained, pass thought extraction in soxhlet using methanol to remove inorganic salt and then placed in a humid oven at $60^{\circ} \mathrm{C}$.

Laboratory analyzes were divided into two phases: petrophysical-physical acquisition, with air porositypermeability, mercury injection porosimetry and acoustic wave velocity; and mineralogical data acquisition with $x$ ray diffraction and scanning electron microscopy.

The porosimeter - permeameter DV-4000 was used for air porosity-permeability analysis, where is possible obtain grain density, air porosity and air permeability. Grain density is calculated from the division of the sample weight by the grain volume, that is obtained by injecting helium gas into a chamber with the sample and calculated using Boyle's Law. Porosity and permeability tests were performed with samples confined at pressures from 500 psi to $1400 \mathrm{psi}$, according with the sample depth. Pore volume was measured using gas expansion's technique by injection of helium gas in the chamber where the sample is confined, applying Boyle's Law. Permeability is determined considering Darcy's Law by decay of unstable pressure with the use of nitrogen gas. Nitrogen is injected (upstream pressure) into the sample and the nitrogen outlet pressure (downstream pressure) is measured.

Mercury Injection Porosimetry was introduced in the petroleum industry in 1949 by Purcell, developing Washburn's initial proposal to determine the pore distribution from the mercury injection data in a porous material (Toledo et al., 1994). Mercury is a non-wetting fluid, such as oil, making it possible to determine the saturation during its intrusion under pressure on a rock (Schön, 2014). This analysis provides porosity, calculated permeability, capillary pressure curve, and pore throat radius distribution. Mercury injection analysis was performed on Micrometics Autopore IV equipment. The mercury intrusion in the porous structure of the sample is divided into low pressure phase, going up to $30 \mathrm{psi}$, and high pressure, that ranges from 30 psi to 60,000 psi. Mercury porosimetry is based on the capillary's law that regulates the penetration of fluids into small pores (Schön, 2014).

Ultrasonic Longitudinal and Transverse Wave Propagation Velocity tests were performed with the AutoLab 1000 system and the PS2 ultrasonic transducer, produced by NER (New England Research). The PS2 transducer is one of the detectors of the system specially designed for the ultrasonic waves tests, where the longitudinal wave velocity (Vp) and two transverse wave propagation velocities ( $\mathrm{Vs}_{1}$ and $\mathrm{Vs}_{2}$ ) are measured, perpendicular to each other. During the analysis the samples were subjected to hydrostatic pressure of 500 psi followed by 1000 psi, returning to 500 psi to finalize the analysis. Propagation velocities were measured by the more traditional method used in laboratory experiments, " picking " of the first peak or the first break. The "picking" of the first break is the time of the first oscillatory energy through the sample (Morschbacher et al., 2010).

For X-ray diffraction samples were analyzed with the diffractometer Bruker D4, where the powder method was applied for whole mineralogical analysis (bulk analysis) and Filter Transfer method, described by Moore \& Reynolds (1997), for clay minerals characterization. Clay minerals were separated from carbonates by acid digestion, and from other siliciclastics by centrifuge. The clay fraction was examined after two different treatments for a better clay mineral recognition: (1) ethylene glycol solvation; and (2) heat treatment at 400 and $550 \mathrm{oC}$.

Bulk and clay diffractograms were evaluated using Jade software (MDI) with the PDF-4 + database (ICDD), for a qualitative evaluation. TOPAS software (from Bruker) was used to quantify the minerals from the bulk analysis by Rietveld method. Whereas for clay diffractograms the quantification was performed by the Reference Intensity Ratio method, considering intensity ratios previously obtained by homogeneous mixtures of the clay minerals. Both quantification techniques were correlated to obtain the mineral percentages in the samples.

Scanning electron microscopy (SEM) is a method based on the emission of electron beams on a surface for imaging. Electrons interact with the sample producing various signals that can be used to obtain information about the surface of the sample. The samples were analyzed with a FEI Model 200 Digital Scanning Electron Microscope and Oxford INCA Energy Dispersive Spectrometer (EDS). The images were generated using an Everhart-Thornley detector (ET detector) under high vacuum conditions and a low field Large Field Detector (LFD) with typical magnifications (at a working distance of $10 \mathrm{~mm}$ ) ranging from $40 \mathrm{X}$ to approximately $6,000 \mathrm{X}$.

\section{Results}

Samples were classified as sparse biomicrite, packed biomicrites, poorly washed bioesparite and dolostones, through microscopic description. The limestones are predominantly constituted by micrite with non-carbonate content in the matrix (impure limestones), planktonic and benthic foraminifera, phosphatic fragments, quartz grains, feldspars, micas, and calcispheres as the most frequent particles in these rocks.

The carbonates were lithologically classified considering the terminology by Giannini (2000) as pure limestones, impure limestones, dolomitic limestones, impure dolomitic limestones, impure dolostone and impure calcitic dolostones. This mineralogical general composition is presented in Figure 1 using the $\mathrm{X}$-ray diffraction data.

The X-ray diffraction data confirmed the impurity of the limestones, consisting mainly of calcite with contents of $50 \%$ to $90 \%$ with a variation in the clay mineral percentage of $1 \%$ to $20 \%$. In the dolostones can be observed $59 \%$ and $79 \%$ of dolomite with $13 \%$ and $8 \%$ of clay minerals, respectively. It was also observed the presence of quartz ranging from 4 to $20 \%$, feldspar ranging from trace to $5 \%$, and accessory minerals with trace contents such as siderite, apatite, pyrite, marcasite 
and gypsum. The dolomite present in all samples is an ankerite, a mineral of the dolomites' group commonly called "ferroan dolomite " due to the presence of iron in its structure.

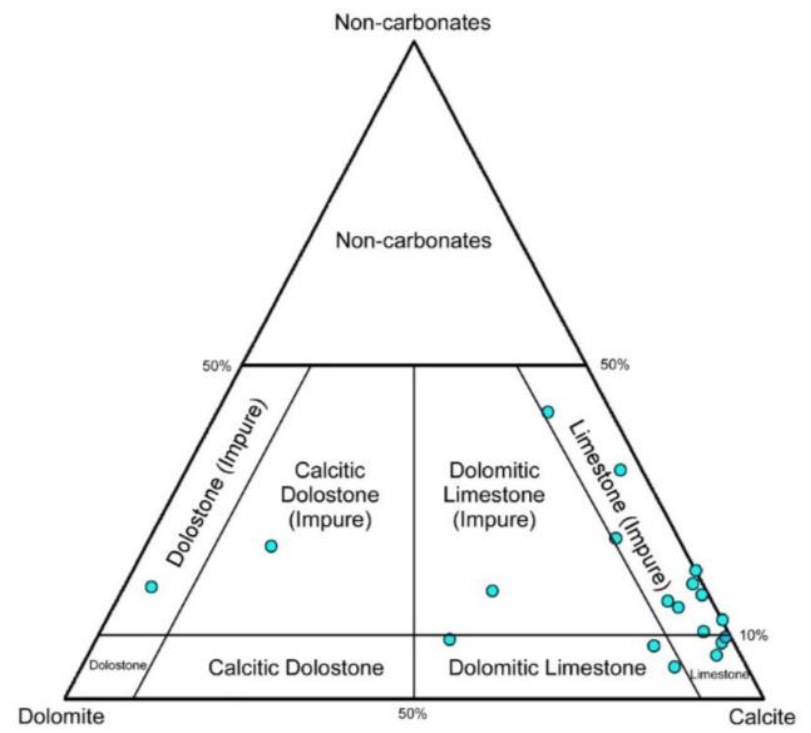

Figure 1: Compositional ternary diagram of carbonates from Cotinguiba Formation, considering Gianni (2000) terminology. Data based on X-ray diffraction.

The clay minerals identified in the carbonates were: (1) chlorite; (2) kaolinite; (3) illites and micas; (4) illite and smectite interstratified; and (5) palygorskite. The illites / micas and illites / smectite interstratified are the main clay minerals found, with contents varying from $1 \%$ to $16 \%$. Palygorskite presence was evidenced in seven of the studied samples with levels ranging from trace to $12 \%$. The chlorite and kaolinite have trace contents, and the main clay minerals are not present.

Clay minerals occurrences can be evidenced in different ways in the analyzed samples: (1) clay films disseminated in the matrix and covering bioclasts; (2) clay lenses forming irregular laminations; (3) clay sheets in the micrite; (4) clay grains with intragranular porosity (Figure 2).

Relationship between grain density and clay mineral content is presented in Figure 3 . It shows that dolostones and dolomitic limestones keep high density (higher than $2.71 \mathrm{~g} / \mathrm{cm} 3$ ) independent of the clay content. Pure limestones have a density of 2.69 and $2.70 \mathrm{~g} / \mathrm{cm} 3$, with little contribution of the secondary mineral composition of these rocks.

Impure limestones have density ranging from 2.64 and $2.71 \mathrm{~g} / \mathrm{cm} 3$. The mineralogical constitution of these rocks is more variable and there is no linear correlation between density decrease and increase of clay content. However, the following relations can be considered: limestones with less than $8 \%$ of clay maintain high densities between 2.70 and $2.71 \mathrm{~g} / \mathrm{cm} 3$; and presence of palygorskite in the samples significantly decreased the density of the samples, with values of 2.64 to $2.68 \mathrm{~g} / \mathrm{cm} 3$.
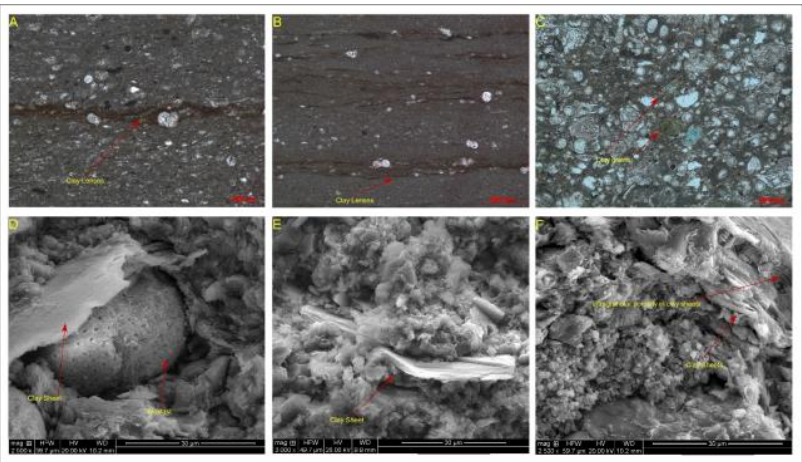

Figure 2: Different occurrences of clays in the carbonates. A) Photomicrography in parallel nicols, clay films covering bioclasts. B) Photomicrography in parallel nicols, clay lenses disseminated in the matrix forming lamination. C) Photomicrography in parallel nicols, with detailed view of clay grains. D) SEM image of clay sheets covering bioclasts. E) SEM image clay sheets in the micrite. F) SEM image clay sheets with intragranular porosity.

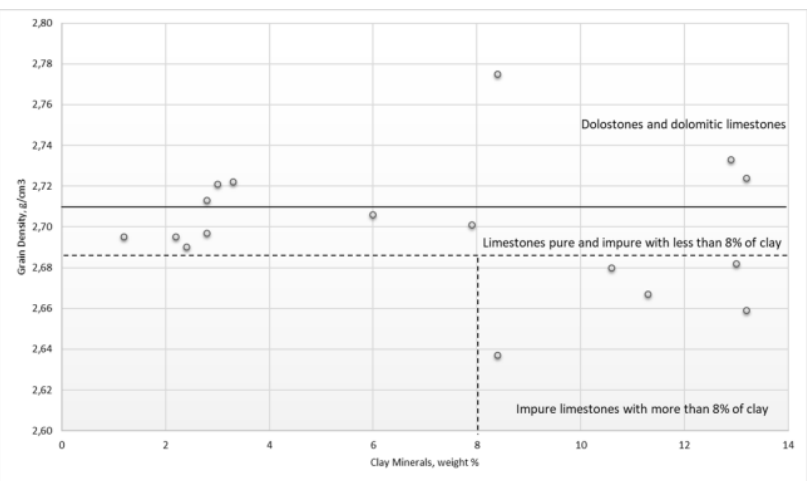

Figure 3: Relationship between grain density and clay mineral content. Presenting separation between dolostones and dolomitic limestones with densities higher than $2.71 \mathrm{~g} / \mathrm{cm} 3$; pure limestones and impure limestone with less than $8 \%$ of clay and density ranging 2.69 and $2.71 \mathrm{~g} / \mathrm{cm} 3$ impure limestone with more than $8 \%$ of clay and density ranging 2.64 and $2.69 \mathrm{~g} / \mathrm{cm} 3$.

The pores observed by microscopy varies to fractures, interparticle, and moldic, with intercrystalline and intraparticle pores being the most common. The porosity of rocks is often reduced by calcite and pyrite cementation, and more rarely by gypsum, that is also observed replacing calcite present in fractures. The determination of porosity and gas permeability showed that the limestones analyzed had a percentage of effective porosity from $8.4 \%$ to $9.1 \%$, impure limestones varied from $6.4 \%$ to $19.3 \%$, dolomitic limestones varied from $8.6 \%$ to $19.8 \%$, and dolostones have porosity of $18.4 \%$ and $19.1 \%$. Despite the good pore quality of the samples, the permeability values found were low with values of $0.0056 \mathrm{mD}$ to $0.0099 \mathrm{mD}$ for limestones, 0.0038 $\mathrm{mD}$ for $0.3041 \mathrm{mD}$ for impure limestones, $0.0081 \mathrm{mD}$ for $0,0713 \mathrm{mD}$ for dolomitic limestones, and $0.1859 \mathrm{mD}$ to $0.0979 \mathrm{mD}$ for dolostones (Figure 4). 


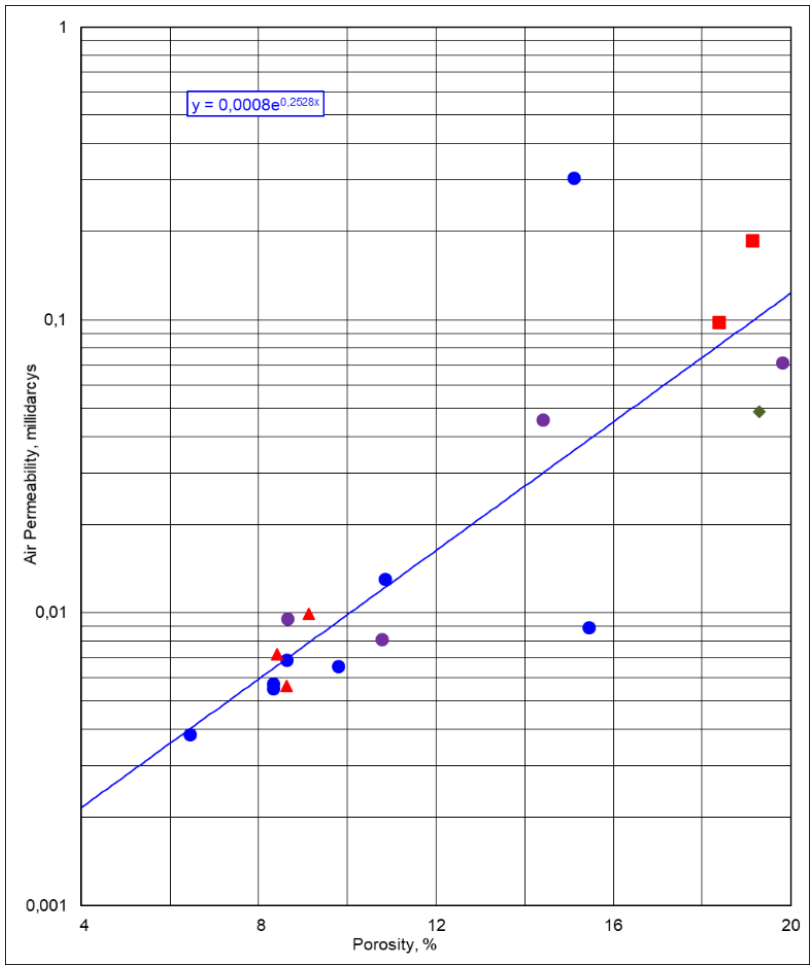

Figure 4: Cross plot between porosity (\%) and permeability $(\mathrm{mD})$. Limestone 0 , Impure Limestone Dolomitic limestone $\mathbf{}$, Impure dolostone $\mathbf{A}$.

Pore Throat Radius distribution obtained by mercury injection was classified considering Carbonate Advisor (Schlumberger) and Cantrell and Hagerty (1999), that confirmed the predominance of microporosity (smaller than $0.5 \mu \mathrm{m}$ ), with limestones showing percentages of $99 \%$ to $100 \%$ of micropores and dolostones have $98 \%$ and $99 \%$ of micropores (Figure 5). Three main types of microporosity were observed: porous matrix, porous grains (carbonate and siliciclastic), and cement with intercrystalline pores (Figure 6).

Eberli et al. (2003) demonstrated that the porosity type is one of the most important factors influencing the acoustic wave velocity in carbonates. Sonic velocity is a response related to the relationship between diagenesis and porosity, in carbonates these velocities has a wide range in which the compressional wave velocity $(\mathrm{Vp})$ can vary from 1700 to $6600 \mathrm{~m} / \mathrm{s}$, and shear wave velocity (Vs) from 600 a $3500 \mathrm{~m} / \mathrm{s}$

As evidenced by Baechle et al. (2008), samples with more than $80 \%$ of microporosity display the lowest velocities at a given porosity. The microporosity can cause lowering in the velocity independent of the predominant mineralogy, for example the calcitic dolostone that could reach high velocity values if related only to its mineralogy, has a Vp of $3541 \mathrm{~m} / \mathrm{s}$. Similar results were observed by Baechle et al. (2008) where dolomites and packstones with high percentages of microporosity have velocities approximately $2500 \mathrm{~m} / \mathrm{s}$ and $3000 \mathrm{~m} / \mathrm{s}$, respectively. Thus, the microporosity of the carbonates of this formation is a main characteristic to reduce the acoustic velocities not exceeding $5341 \mathrm{~m} / \mathrm{s}$ for $\mathrm{Vp}$ and $3026 \mathrm{~m} / \mathrm{s}$ for Vs.

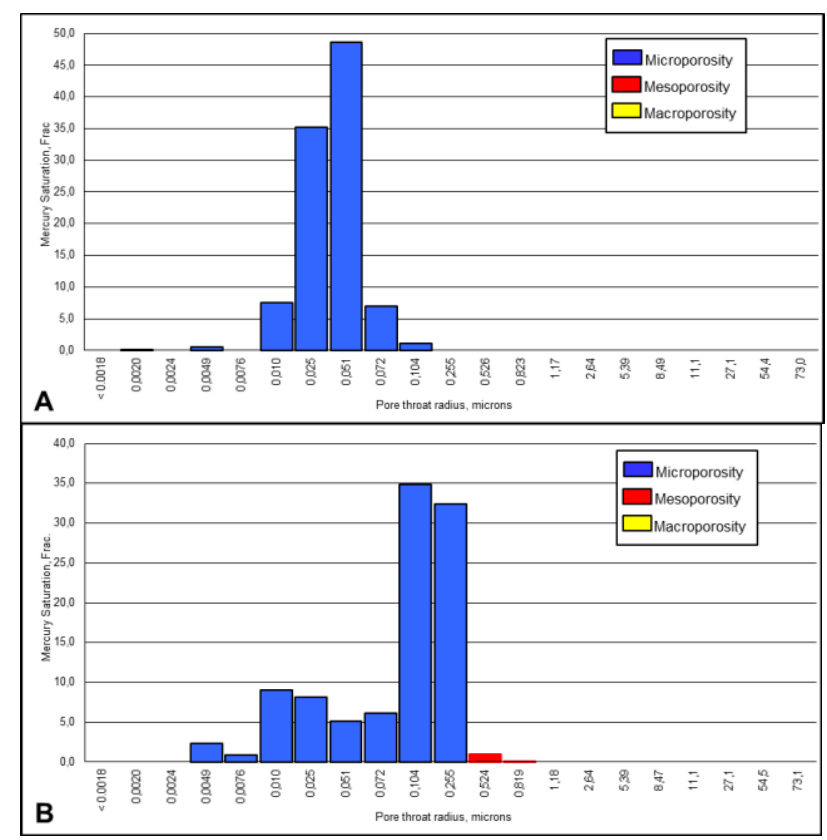

Figure 5: A) Histogram from limestone with 100\% microporosity. B) Histogram from limestone with $99 \%$ microporosity and $1 \%$ mesoporosity.

Figure 7 presents the results of $\mathrm{Vp}$ and $\mathrm{Vs}$ of the studied rocks separated into two groups. Group I with Vp values less than $4500 \mathrm{~m} / \mathrm{s}$ and Vs equal or less than $2500 \mathrm{~m} / \mathrm{s}$; and Group II with Vp higher than $4500 \mathrm{~m} / \mathrm{s}$ and Vs higher than $2500 \mathrm{~m} / \mathrm{s}$.

Eberli et al. (2003) concluded in their study on the factors controlling elastic properties in carbonates, that siliciclastic content in carbonates is a much less important factor. Nevertheless, it was pointed in their paper that insolubles (mainly clay) decrease velocity in carbonates and velocities faster than $4000 \mathrm{~m} / \mathrm{s}$ are only reached if the clay content is below $5 \%$.

Cross plot between clay mineral content and $\mathrm{Vp}$ showed that rocks with faster velocities have a clay mineral content lower than 3\% (Figure 8 ). There is no linear relationship between the increase of clay minerals and their influence on velocity, but it can be observed that together with the other parameters the argilosity of the carbonaceous rocks can influence the acoustic properties. 


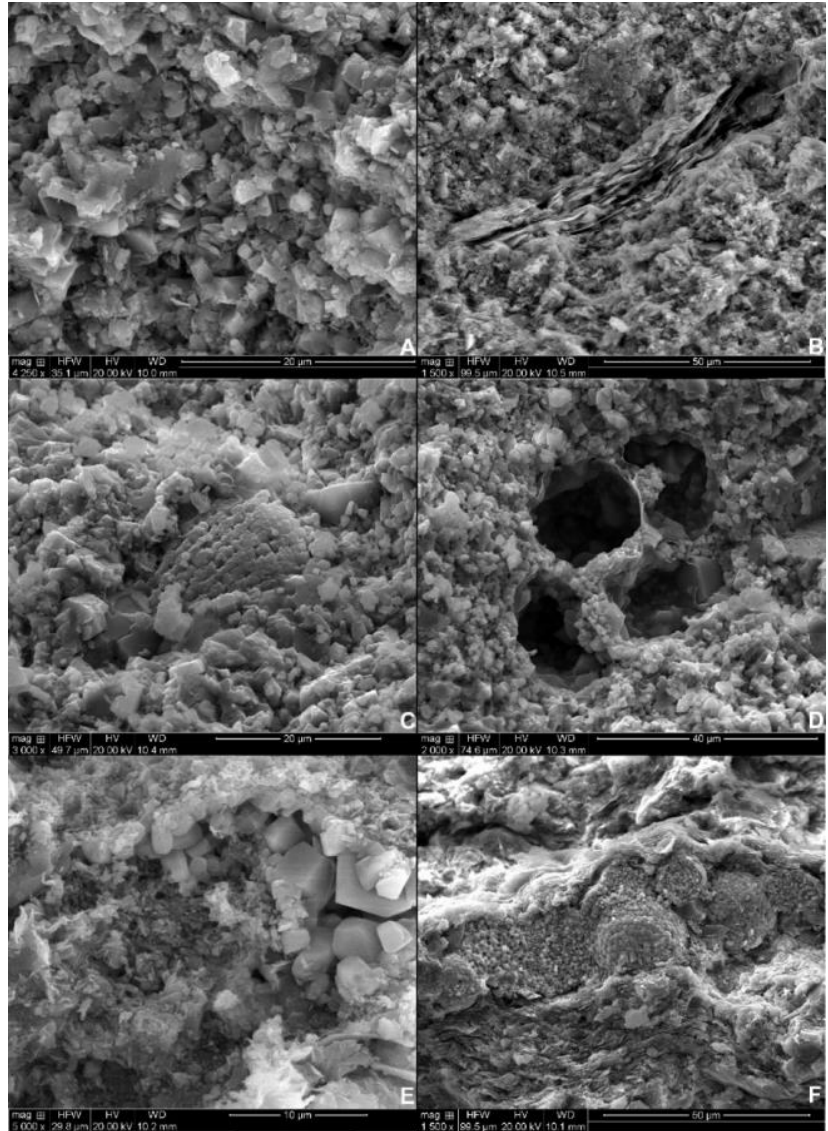

Figure 6: SEM images with evidence of micropores. A) Porous matrix. B) Porous matrix with clay lenses with intragranular pores. C) Porous bioclast. D) Porous bioclasts with intragranular porosity. E) Calcite cement with intercrystalline pores. F) Framboidal pyrite cement with intercrystalline pores.

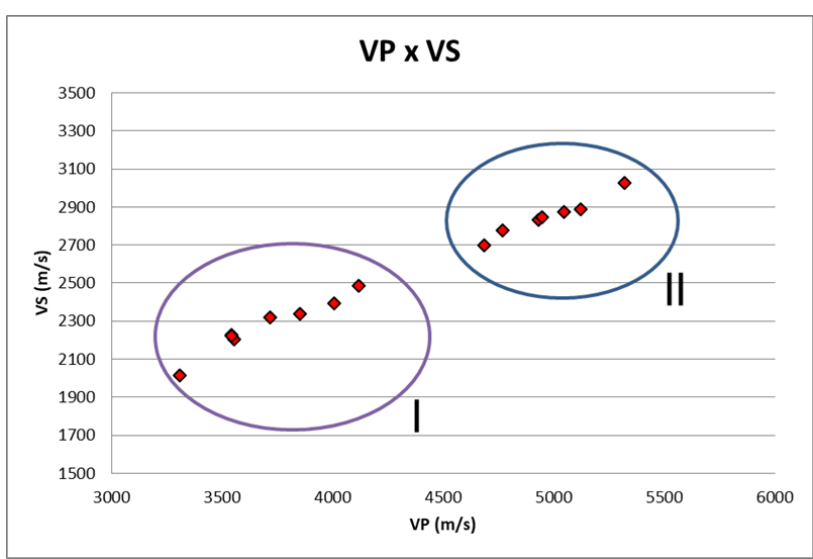

Figure 7: Graph Vp x Vs1 with separation of two identified groups.

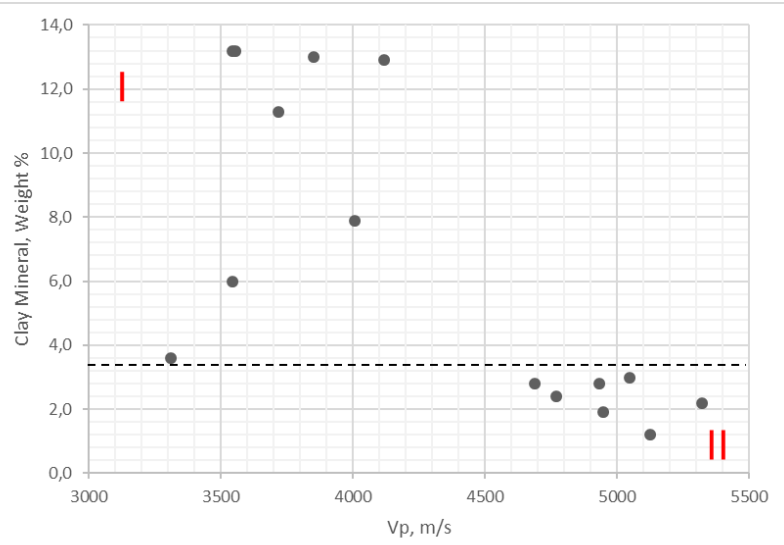

Figure 8: Relationship between clay mineral content and $\mathrm{Vp}$, with separation of two identified groups.

\section{Conclusions}

The carbonate rocks from Cotinguiba Formation showed: (1) high density due to the calcite and dolomite content; (2) good porosity of the rocks predominantly related to microporosity; (3) low permeability due to the low connectivity of these pores; and (4) acoustic waves segregated in two groups.

The presence of non-carbonate constituents in limestones and dolostones between $5 \%$ and $43 \%$ shows the importance of these minerals in the formation of these rocks. Through the results obtained it was possible to confirm the influence of the clay minerals on the physical and petrophysical properties of the carbonates from Cotinguiba Formation. The most abundant clay minerals in most rocks are illites/micas and interstratified illite/smectite, with the trace chlorite and kaolinite in most samples. The palygorskite was found in seven samples with varying levels of trace to $12 \%$.

Clay significance was more evident in grain density and acoustic properties. The grain density variation in relation to clay mineral content was observed more significantly in impure limestones with a clay content higher than $8 \%$, mainly in the samples that present palygorskite, with values of 2.64 to $2.68 \mathrm{~g} / \mathrm{cm} 3$. Clay content higher than $4 \%$ lowered acoustic waves $\mathrm{Vp}$ and $\mathrm{Vs}$ that do not exceed $4100 \mathrm{~m} / \mathrm{s}$ and $2480 \mathrm{~m} / \mathrm{s}$, respectively.

The correlation between clay content with porosity and permeability values showed that the influence of these minerals in micritic carbonaceous rocks does not have an inverse proportional linearity, clay content is not a main factor in the decrease of porosity and permeability. However, SEM images showed the presence of clay sheets filling intercrystalline and intraparticle pores, as well as having intragranular pores between the clay sheets, demonstrating their influence on the predominant microporosity in these samples.

Therefore, it has been demonstrated here that the presence of clay minerals in the carbonate rocks of the Cotinguiba Formation is common and with a differentiated mineralogical variation, having palygorskite in part of the 
samples. The petrophysical and physical properties of these samples do not vary directly or inversely proportional to the increase of the mineral content of clay, but they influence in a particular way all the properties.

\section{Acknowledgments}

To Professor Leonardo Borghi de Almeida, from the Laboratory of Sedimentary Geology (LAGESED), as well as the research group of LAGESED for making available the samples for this study and assisting in the selection of these;

To the Petrobras Research Center (CENPES), in the person of the geophysicist Júlio Cesar Ramos Justen for the support in the realization of the acoustic wave velocity analysis.

To Weatherford Laboratories for the support given in conducting the analyses, and to the various professionals of the company who helped with the processing and interpretation of the results.

\section{References}

Baechle, G.T., Eberli, G.P., and Weger, J., 2008, Effects of microporosity on sonic velocity in carbonate rocks: The Leading-Edge Special Section: Carbonates, 1012-1018.

Bandeira JR., A.N., 1977, Sedimentologia e microfacies calcárias das Formações Riachuelo e Cotinguiba da Bacia Sergipe/Alagoas: M.S. thesis, Universidade de São Paulo.

Campos Neto, O.P.A., Lima, W.S., and Cruz, F.E.G., 2007. Bacia de Sergipe-Alagoas: Boletim de Geociências Petrobrás, Rio de Janeiro, 15, 405-415.

Cantrell, D.L., and Hagerty, R.M., 1999, Microporosity in Arab Formation Carbonates, Saudi Arabia: GeoArabia, 4, 129-.154.

Carbonate Advisor, Schlumberger, 2008, Quantitative producibility and textural analysis for carbonate reservoirs, www.slb.com/carbonates, accessed 10 July 2018.

Eberli, G.P., Baechle, G.T., Anselmetti, F.S., and Incze, M.L., 2003, Factors controlling elastic properties in carbonate sediments and rocks: The Leading Edge, 22, 654-660.

Feijó, F.L., 1994, Bacia de Sergipe e Alagoas: Boletim de Geociências Petrobrás, Rio de Janeiro, 8, 149-161.

Giannini, P.C.F., 2000, Depósitos e rochas sedimentares, in W. Teixeira, T.R. Fairchild, M.C. Toledo, F. Taioli. ed., Decifrando a Terra (capítulo 14). São Paulo, Oficina de Textos, 301.

Koutsoukos, E.A.M., 1989, Mid- to Late Cretaceous microbiostratigraphy, palaeo-ecology and palaeogeography of the Sergipe Basin, northeastern Brazil: Council for National Academic Awards, Polytechnic South West, Plymouth, UK, 2 volumes, 886.
Monteiro, R.S., 2017, Caracterização Microfaciológica Da Formação Cotinguiba (Cretáceo Superior, Bacia De Sergipe-Alagoas) Em Testemunho De Sondagem: M.S. thesis, Universidade Federal do Rio de Janeiro.

Moore, D.M., and Reynolds, R.C., 1997, X-Ray Diffraction and the Identification and Analysis of the Clay Minerals: Oxford University Press, Inc.

Morschbacher, M.J., Vasquez, G.F., and Justen, J.C.R., 2010, Metodologias de estimativa das velocidades sísmicas em ensaios de laboratório: 4ํㅗ Simpósio Brasileiro de Geofísica, Brasília.

Schön, J.H., 2014, Propriedade Física das Rochas Aplicadas à Engenharia: Elsevier Editora Ltda.

Spadini, A.R., and Marçal, R.A., 2004/2005, Porosidade em reservatórios carbonáticos: algumas considerações: Boletim de Geociências da Petrobras, Rio de Janeiro, 13, 129-138.

Toledo, P.G., Scriven, L.E., and Davis, H.T., 1994, PoreSpace Statistics and Capillary Pressure Curves from volume-controlled porosimetry: SPE Formation Evaluation, 46-54. 